\title{
The Effect of Application of Learning Models with Saintific Approach to Learning Outcomes and Creatifivity of Students
}

\author{
Molani Paulina Hasibuan ${ }^{1}$ and Ratih Permana Sari ${ }^{2}$ \\ $\left\{\right.$ molanipaulinahsb@unsam.ac.id $\left.{ }^{1}\right\}$ \\ Chemistry Education Department, Universitas Samudra ${ }^{1,2}$ \\ Kampus UNSAM Meurandeh-Langsa 24416
}

\begin{abstract}
This study aims to determine the effect of the application of scientific learning models in improving chemistry learning outcomes on aspects of students' cognitive knowledge and creativity. This research was conducted in SMAN 1 Langsa in JanuaryJune 2018. The research method used was an experimental method with a sample of 120 students in class $X$. The instrument used was a test question and then analyzed with the Spearman Rank correlation test using the SPSS program while to see students' creativity using the questionnaire method. The results showed the achievement of the 2013 curriculum-based scientific learning model implementation of PBL and PjBL occupied the highest position from the cognitive aspect, followed by DBL and IBL because PBL and PjBL enabled students to solve problems with active participation. Based on the results of data analysis both pretest and posttest given to each class using SPPS it was found that there was a positive influence on student learning outcomes and creativity after the application of the 2013 curriculum-based learning model.
\end{abstract}

Keywords: Learning Model, Scientific Approach, Learning Outcomes and Creatifivity

\section{Introduction}

National development priorities as outlined in the PlanNational Long Term Development (RPJP)Year 2005 - 2025 (Law No. 17 of 2007)among others is in realizingpeople who are noble, moral,ethical, cultured, and civilized based Pancasila philosophy ". One attempt torealizing it is by the waystrengthen the identity and character of the nation througheducation. This effort aims toforming and building Indonesian peoplewho is devoted to God Almighty, obey the rule of law, maintain harmony internal and inter-religious, carry outintercultural interaction, developing capitalsocial, applying cultural noble values nation, and has pride as Indonesian people in order to establishspiritual, moral and ethical foundation National development.

National education functions develop abilities and shape dignified national character and civilization in order to educate the life of the nation, which aims to develop potential students to become human beings believe and fear God Who Almighty, noble, healthy, knowledgeable, competent, creative, independent, and a citizen a democratic and responsible country answer. Education is an important part from human life that can never be abandoned [1].

In 2013, the government began implementing the 2013 curriculum as one of the efforts to improve the quality of education in Indonesia. Implementation of the 2013 Curriculum is 
expected to produce graduates who are productive, creative, and innovative [2]. This is possible because this curriculum is based on character and competence. This 2013 curriculum emphasizes the activeness of students in the teaching and learning process. Students are required to be able to master the learning material with their own abilities with the creativity of each individual to understand the concept of the material, while the teacher is only as a facilitator in learning.

In the implementation of the 2013 curriculum the teacher is required to professionally design effective and meaningful learning, organize learning, choose the right learning approach, determine effective learning and competency formation procedures, and set success criteria. The implementation of the 2013 curriculum which is full of character and competence, should be accompanied by a full, continuous, and continuous assessment in order to reveal various aspects of assessment such as aspects of knowledge, attitudes and skills as a whole and proportionally, in accordance with predetermined core competencies [3].

In the Minister of Education and Culture Regulation No. 69 of 2013 concerning KD and curriculum, chemistry is one of the subjects in the 2013 curriculum. Chemistry is the learning that is included in the 2013 curriculum which includes the scientific approach. Successful learning processes require certain models according to the characteristics of the students' goals, materials, and resources, so that appropriate and effective strategies are needed. One of the important objectives of chemistry subjects in high school is that students understand concepts, principles, laws, chemical theories and their application to solve problems in everyday life [4].

According to [5], the inclusion of the character through the study of religion and nationality is not enough. This is because both the new subjects encompass cognitive knowledge about values. Religion and nationality learning activities not encourage internalization of values. Character education needs to involve all disciplines. However, teachers are still lacking in attention to character development, especially high school teacher. High school teacher only focus on the material that they teach [6].

According to respondents experts, character education in chemistry learning can be organized through the nature of the chemical itself, which includes products, processes, and attitudes. Chemical products which include principles, laws, and theories can foster a sense of awe at God. Chemical products reveal about regularity, equilibrium

processes, and benefits for life. A sense of awe in God can develop religious character, the character of the subject to be possessed learners. According to [2], the chemical process is a procedure in solving problems that include: (1) identification of the problem, (2) the formulation of a hypothesis, (3) designing an investigation, (4) investigation, (5) data collection and analysis, (6) drawing conclusions, (7) the communication results of the investigation.

Chemical process can introduce learners other things about the character of an honest, curious, objective, able to work, logical thinking, critical, creative, and innovative. Attitudes can be curiosity be a natural phenomenon, causality can be solved through proper procedures. Respondents teachers have not looked through the cultivation of character chemical integrative.Some consider planting a character through the material or chemical products, in part through a chemical process. So it is still necessary socialization about how the chemistry learning organized for the establishment and development of character [7].

Curriculum 2013 that applies today in Indonesia,in essence it is not an educational formulanew ones, but it is an advanced stage of previous curriculum, based curriculum Competence (KBK) 2004 and Level curriculum 2006 Education Unit (KTSP). Curriculum 2013 is also called a competency-based curriculum and character. In the 2013 curriculum for 
high school level in Indonesia, has components that have new concepts in it which is an improvement of the curriculum KTSP [4].

The implementation of the 2013 curriculum that has not been comprehensive and its application is still relatively new in schools has caused its implementation in teaching and learning activities to be not optimal [8]. One important aspect to be considered for the smooth implementation of the 2013 curriculum is the application of the scientific approach as one of the approaches in this curriculum. A successful learning approach that requires a particular model so that an appropriate and effective strategy is needed.

For that, the most effective learning model is needed to obtain optimal learning outcomes, both learning outcomes in terms of cognitive students. Learning models that have scientific approaches include Inquiry Based Learning (IBL), Problem Based Learning (PBL), Project Based Learning (PBjL), and Discovery Based Learning (DBL). Of the four learning models, it is possible to have the most optimal scientific learning model in the process so that the objectives of the 2013 curriculum implementation can be obtained with optimal results as well.

\section{Method}

\subsection{Participant and Design}

The method used in this research is the experimental method. This research is a quantitative research with quantitative descriptive problem formulation. Descriptive problem formulation in this study to see the effect of the implementation of the 2013 curriculum that has been implemented on improving student learning and creativity.

This research was carried out in SMAN 1 in Langsa City, Aceh Province, in the tenth semester of the odd semester of 2018/2019 academic year. The study carried out six meetings from the beginning of the material until the material was completed, the meeting consisted of one time for habituation and five times for the learning process.

\subsection{Measurement}

Collecting data in this study through test and observation techniques. To get the data that answers this research question, the authors compile an instrument consisting of test questions and observation sheet instruments. The preparation of instruments through several stages, namely the selection of test items, translation, translation validation, readability and revision tests.

Data analysis techniques in the study used three activities flow, namely: 1) statistical data processing, 2) data presentation, and 3) conclusion or verification of data. Statistical data processing using SPSS program. To provide an overview, data analysis is expressed in proportion correct form. Proportion correct is calculated using the formula:

Information:

$$
\mathrm{p}=\mathrm{JB} / \mathrm{N}
$$

$\mathrm{P}=$ proportion correct

$\mathrm{JB}=$ total score obtained by all students on certain test items

$\mathrm{N}=$ total score if all students correctly answer certain test items 
Meanwhile, to find out whether there are significant differences in learning outcomes of students taught with the IBL, PBL, PRL, and DL models, One Way Anova test is conducted if the data is normally and homogeneously distributed or the Kruskal Wallis test if the data is not normally distributed and is not homogeneous using SPSS program. As for knowing whether there is a effect between cognitive knowledge learning outcomes and learning outcomes of creatificatin formation, the regretion test was conducted using the SPSS program.

\section{Results}

\subsection{Achievement of 2013 Curriculum Implementation Judging from Cognitive Aspects}

Based on the analysis of research data from the instrument questions given to class $\mathrm{X}$ students of SMA Negeri 1 Langsa consisting of four classes after being given different treatment obtained results of Problem Based Learning Model get the highest n-gain value among other learning models. This means that the implementation of the 2013 curriculum through four models of scientific approaches, PBL models have a greater chance of actively creating students when viewed from a cognitive aspect. The cognitive aspect that is intended is that students are able to solve the given questions and are able to go through the stages in observing, formulating problems, collecting data, drawing conclusions and communicating the concept of hydrocarbon principles. Graph of achievement of 2013 curriculum implementation in terms of cognitive aspects can be seen below.
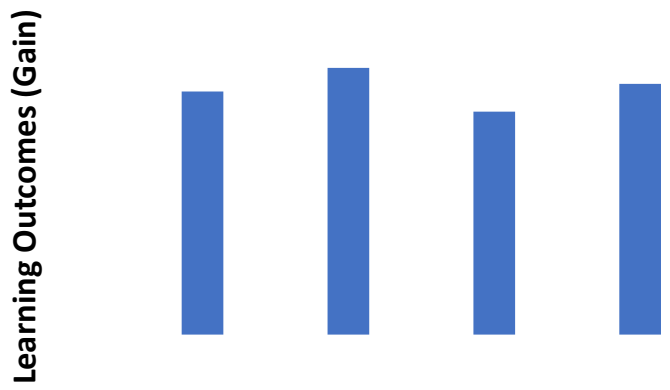

\section{Learning Models in 2013}

Fig. 1. Graph of Achievement of 2013 Curriculum Learning Model Implementation Judging from Cognitive Aspects

Based on the results of data analysis both pretest and posttest given to each class using SPPS, it was found that there were significant differences in learning outcomes and student character formation after the application of the 2013 curriculum-based learning model. This can be seen in the table below. 
Table 1. Anova Table 2013 Curriculum-Based Learning Model for SMAN 1 Langsa with student learning outcomes

\begin{tabular}{lll}
\hline & F & Sig. \\
\hline Learning Outcomes & 4.838 & 0.037 \\
Conclusion & Differences
\end{tabular}

Table 1 shows that Before continuing the test it should be remembered that one of Anova's assumptions is the same variance. From the Test of Homegeneity of Variances table, it can be seen that the test results show that the variants of the three groups are the same $(\mathrm{P}$ value $=0.067$ ), so the Anova test is valid to test this relationship. Next to see whether there are significant differences in the application of the four 2013 curriculum learning models to student learning outcomes.

We see the ANOVA table, from the table in the Sig. obtained $\mathrm{P}$ value $(\mathrm{P}$-value $)=0.037$. Thus in the real level $<0.05$ we reject Ho, so the conclusion obtained is that there is a significant difference in the average learning outcomes based on the application of the four learning models.

\subsection{Achievement of 2013 Curriculum Implementation Judging from the Aspects of Character Building That is Creativity}

Furthermore, based on the analysis of research data from questionnaire instruments with character indicators in the form of creativity, the results obtained for SMAN 1 Langsa PjBL get the highest percentage value among other learning models. The difference in the percentage of creativity is influenced by the availability of facilities and infrastructure for preparing tasks given by the teacher. SMAN 1 Langsa has more complete laboratory facilities, therefore students are very enthusiastic in creating their chemical work.

Graphs of the 2013 curriculum implementation achievements in terms of character building aspects on the creativity indicators can be seen below.

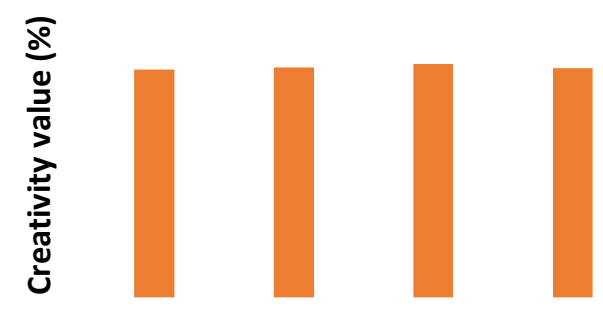

Learning Models in 2013

Fig. 2. Graph of Achievement of Implementation of 2013 Curriculum Learning Models Against Student Creativity 


\section{Discusion}

The achievement of the 2013 curriculum learning model implementation for SMAN 1 Kota Langsa shows that the problem-based learning model occupies the highest position of the cognitive aspects, followed by DBL, IBL and PjBL. PBL Allows students to solve problems with active participation. In PBL, students work with others and reflect on what they have learned. Students can be active in search and decision-making processes by increasing their practical thinking skills [9].

This result is also the same as the research conducted by [10] where the teacher in the field of study stated that the PBL model was accompanied by a good task applied in chemistry learning, because students were more active and had direct experience in solving chemical problems through experiments.

Furthermore, PjBL gets the lowest gain value compared to other learning models both in SMAN 1 in Langsa City. This is due to the availability of project material that must be prepared by students, the availability of time to complete the project as well as the lack of teachers who guide students in working on the project [11]. As is known, the design principle of PjBL includes a context that involves students in an extension of authentic inquiry through preliminary questions, collaborative work that allows students to communicate their ideas, learn technology to find and deliver solutions and from those activities created artifacts that students will demonstrate as a basis for discussion, feedback, and revision [12]. This is similar to the research conducted by (Surya, et al., 2018) where the time spent in project learning was felt to be lacking because there was a lot of time spent in group discussions and presentations so that material reinforcement was felt to be lacking in the classroom learning process.

Based on the results of the research that has been done it was found that the application of 2013 curriculum-based learning models such as IBL, PBL, PjBL and DBL are learning models that train and develop the ability to solve problems that are oriented to authentic problems from the actual life of students and stimulate higher-order thinking skills. This is consistent with one of the studies conducted by [13] where problem-based learning (PBL) is learning gained through the process towards understanding the resolution of a problem. The problem is first met in the learning process that is able to provide motivation and curiosity to increase as well as make changes in learning, especially in terms of the role of the teacher.

\section{Conclusion}

The results of the study based on the data found were:

1. Achievement of the 2013 curriculum learning model implementation both for SMAN 1 Langsa city shows the PBL model occupies the highest position from the cognitive aspect, followed by DBL, IBL and PjBL this is because PBL allows students to solve problems with active participation.

2. Based on the results of data analysis both pretest and posttest given to each class using SPPS, it was found that there were significant differences in learning outcomes and character building of students after the application of the 2013 curriculum-based learning model.

3. Based on the results of data analysis both pretest and posttest given to each class using SPPS, it was found that there were significant differences in learning outcomes 
and student character about creatifity formation after the application of the 2013 curriculum-based learning model.

\section{Reference}

[1] Ramli.: "Pendidikan Karakter Dalam Dunia Pendidikan," (2003)

[2] W. Ambarsari and S. Santosa.: "Penerapan Pembelajaran Inkuiri Terbimbing Terhadap Keterampilan Proses Sains Dasar Pada Pelajaran Biologi Siswa Kelas VIII SMP Negeri 7 Surakarta," J. Pendidik. Biol., vol. 5, no. 1, pp. 81-95. (2013)

[3] I. Kurniasih and B. Sani.: "Implementasi Kurikulum 2013 Konsep dan Penerapan," Kementrian Pendidik. dan Kebud., pp. 1-162 (2014)

[4] A. R. Clorawati, S. Rohiat, and H. Amir.: "Implementasi Kurikulum 2013 Bagi Guru Kimia," vol. 1, no. 2, pp. 132-135 (2017)

[5] I. Setiawan, N. Y. Indriyanti, and S. Mulyani.: "Profil Pembelajaran Kimia Berbasis Kurikulum 2013 Di Kota Gorontalo Dan Kota Surakarta Kelas X Tahun Ajaran 2016 / 2017. (2017)

[6] R. D. Desriyanti and L. Lazulva.: "Penerapan Problem Based Learning Pada Pembelajaran Konsep Hidrolisi Garam Untuk Meningkatkan Hasil Belajar Siswa,” J. Tadris Kim., vol. 1, no. 2, p. 70 (2016)

[7] K. Iii, S. D. Negeri, and S. Lor.: “1 , 2 , 3,” vol. 6, no. 1, pp. 41-54 (2018)

[8] T. Surur, M. and D. M. Handarini.: "Keefektifan Problem Solving Strategy ( Pss ) Untuk Meningkatkan Keterampilan Memecahkan Masalah Pada Siswa Smp," J. Pendidikan, Teor. dan Pengemb., vol. 1 Nomor 11, no. Nopember, pp. 2211-2219 (2016)

[9] T. Penerapan, K. Dan, and K. Di.: “Analisis Perbandingan Hasil Belajar Kimia Siswa," vol. 5, no. 1, pp. 94-101 (2017)

[10] Husni.: "Implementasi Pembelajaran Kimia Berbasis Lingkungan dengan Model Problem Based Learning (PBL) untuk Meningkatkan Minat dan Keterampilan Berpikir Kritis pada Siswa SMA," Lantanida J., vol. 3, no. 2, pp. 156-167 (2015)

[11] I. Barlenti, M. Hasan, and Mahidin.: "Pengembangan LKS Berbasis Project Based Learning untuk Meningkatkan Pemahaman Konsep,” J. Pendidik. Sains Indones., vol. 5, no. 1, pp. 81-86 (2017)

[12] D. Anggraini.: "Pengembangan Karakter Siswa Pada Pembelajaran Kimia Berbasis Teknologi Informasi Menggunakan Metode Diskusi," (2014)

[13] Masyhuri, A. D. Lesmono, and D. Handayani.: "“ Model Problem Based Learning ( Pbl ) Disertai Tugas Dalam Pembelajaran Fisika Di Sma ," J. Pembelajaran Fis., vol. 6, no. 4, pp. 418426, (2017) 